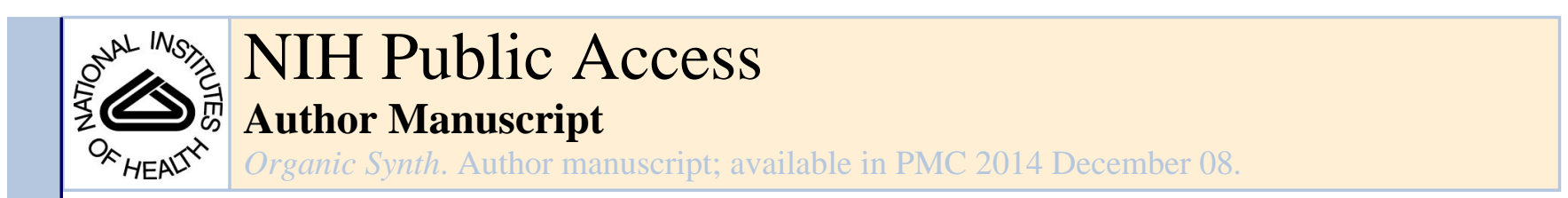

Published in final edited form as:

Organic Synth. 2012 ; 89: 183-201. doi:10.1002/0471264229.os089.19.

\title{
Preparation of 1-Monoacylglycerols via the Suzuki-Miyaura Reaction: 2,3-Dihydroxypropyl (Z)-tetradec-7-enoate
}

\author{
Dexi Yang ${ }^{1}$, Valerie A. Cwynar ${ }^{1}$, David J. Hart ${ }^{1}$, Jakkam Madanmohan ${ }^{1}$, Jean Lee ${ }^{2}$, Joseph \\ Lyons $^{2}$, and Martin Caffrey ${ }^{2}$ \\ David J. Hart: hart@chemistry.ohio-state.edu
}

${ }^{1}$ The Ohio State University, Department of Chemistry, 100 W. 18th Avenue, Columbus, $\mathrm{OH}$ 43210, USA ${ }^{2}$ Department of Chemical and Environmental Sciences, University of Limerick, Limerick, and Schools of Medicine and Biochemistry and Immunology, Trinity College, Dublin, Ireland

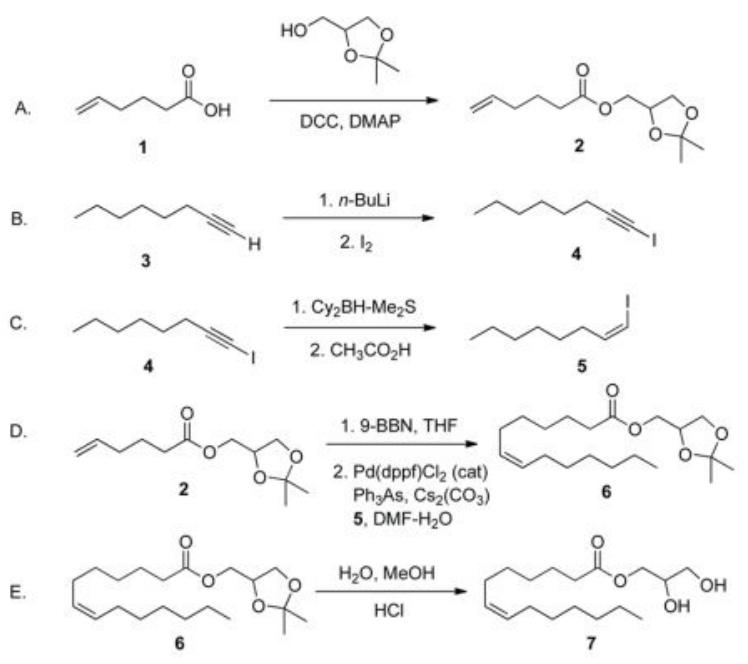

\section{Procedure}

A. (2,2-Dimethyl-1,3-dioxolan-4-yl)methyl 5-Hexenoate (2)

A flame-dried, 250-mL, three-necked round-bottomed flask equipped with a oval-shaped magnetic stir bar $(4 \mathrm{~cm} \times 1.5 \mathrm{~cm})$ and three rubber septa is charged via plastic syringe with 5-hexenoic acid (5.30 mL, $5.09 \mathrm{~g}, 44.6 \mathrm{mmol})$, dichloromethane (70 mL), and DL-1,2isopropylideneglycerol (5.60 mL, $5.95 \mathrm{~g}, 45.0 \mathrm{mmol}, 1.01$ equiv) (Note 1). A septum is removed, solid 4-(dimethylamino)pyridine ( $55 \mathrm{mg}, 0.45 \mathrm{mmol}, 0.01$ equiv) (Note 1) is added through the open neck, the septum is replaced, and the flask is evacuated $(<1 \mathrm{mmHg})$

\footnotetext{
() 2012 Organic Syntheses, Inc.

15-Hexenoic acid (98\%) was purchased from TCI Americas and used as received. DL-1,2-Isopropylideneglycerol ("solketal," 98\%), 4-dimethylaminopyridine (99\%), and dicyclohexylcarbodiimide (99\%) were purchased from Aldrich and used as received. Dichloromethane was purchased from Fisher (Certified ACS, stabilized), and dried by passage over activated alumina (Innovative Technology Inc. Pure Solv ${ }^{\mathrm{TM}}$ solvent purification system). The submitters purchased dichloromethane from Mallinckrodt (ACS reagent grade) and used as received. Submitters used glass syringes in experiments where checkers used plastic syringes.
} 
and refilled with nitrogen before a septum is quickly replaced with a thermometer inlet adapter containing a low temperature thermometer. The flask is submersed in an ice/water bath, and the reaction mixture is allowed to stir gently until its temperature reaches $3-4{ }^{\circ} \mathrm{C}$. Concurrently, a flame-dried, $100-\mathrm{mL}$ recovery flask is charged with $N, N^{\prime}$ dicyclohexylcarbodiimide $(9.28 \mathrm{~g}, 45.0 \mathrm{mmol}, 1.01 \mathrm{equiv})$ (Note 1). The flask is sealed with a rubber septum, evacuated $(<1 \mathrm{mmHg})$ and refilled with nitrogen, then charged with dichloromethane $(15 \mathrm{~mL})$ using a $20-\mathrm{mL}$ plastic syringe, and swirled gently to dissolve the solid. The resulting solution is added dropwise over $15 \mathrm{~min}$ to the stirred reaction mixture using a 20 -mL plastic syringe (Note 2). A white precipitate appears about 5 min into the addition. At no point does the internal temperature rise above $6{ }^{\circ} \mathrm{C}$. To achieve quantitative transfer, the recovery flask is rinsed with approximately $5 \mathrm{~mL}$ dichloromethane, and the resulting solution is added to the reaction mixture in one portion via a $20-\mathrm{mL}$ plastic syringe. Upon completion of the addition, the reaction mixture is allowed to stir for 5 min before the cold bath is removed. After $3.5 \mathrm{~h}$, the precipitate is removed via vacuum filtration (150 $\mathrm{mmHg}$ ) through a Büchner funnel. The reaction flask is rinsed with an additional $50 \mathrm{~mL}$ of dichloromethane, which is poured into the Büchner funnel. The filtrate is concentrated by rotary evaporation $\left(<30{ }^{\circ} \mathrm{C}, 20 \mathrm{mmHg}\right)$ to give a clear, colorless oil that contains a small amount of white solid. The crude product is purified by flash chromatography on silica gel (Note 3$)$ to give $9.25 \mathrm{~g}(91 \%)$ of ester 2 as a clear, colorless oil (Note 4$)$.

\section{B. 1-lodo-1-octyne (4)}

A flame-dried, 500-mL, three-necked round-bottomed flask under an atmosphere of nitrogen and equipped with a oval-shaped magnetic stir bar $(4 \mathrm{~cm} \times 1.5 \mathrm{~cm})$, a $250-\mathrm{mL}$ pressureequalizing addition funnel, a low temperature thermometer, and a rubber septum is charged via 20 -mL plastic syringes with 1-octyne (3) $(14.75 \mathrm{~mL}, 11.02 \mathrm{~g}, 100.0 \mathrm{mmol})$ and hexanes $(125 \mathrm{~mL})$ (Notes 5 and ${ }^{6}$ ). The resulting opaque solution is cooled with gentle stirring in an acetone/dry ice bath to an internal temperature of $-52{ }^{\circ} \mathrm{C}$ (Note 7). The stirring rate is increased, and a solution of $2.5 \mathrm{M} n$-butyllithium in hexanes $(40.0 \mathrm{~mL}, 100 \mathrm{mmol}, 1.0$ equiv) (Note 5) is added dropwise over $20 \mathrm{~min}$ via a $20-\mathrm{mL}$ plastic syringe. A white

\footnotetext{
${ }^{2}$ The submitters used a 50-mL addition funnel equipped with a Newman stopcock.

3 Silica gel was purchased from Zeochem (ZEOprep 60, 40-63 micron particle size). A flash column is prepared by wet-packing a 7.5 $\mathrm{cm}$ diameter column with a slurry of $200 \mathrm{~g}$ silica in $15 \%$ ethyl acetate/hexanes [ethyl acetate and hexanes (both Certified ACS) were purchased from Fisher or Mallinckrodt and used as received]The crude compound is loaded neat, and eluted with 15\% ethyl acetate in hexanes. Fractions $(50 \mathrm{~mL}$ ) are collected and analyzed by TLC (Whatman $0.25 \mathrm{~mm} 60 \AA$ A silica gel plates; $4: 1$ hexanes:ethyl acetate eluent; potassium permanganate stain). The desired ester (2) begins to elute after $\sim 180 \mathrm{~mL}$ of eluent is collected and continues to elute over $\sim 1 \mathrm{~L}$.

${ }^{4}$ Ester 2 exhibits the following spectral properties: IR (neat) $\mathrm{cm}^{-1}: 1740 ;{ }^{1} \mathrm{H} \mathrm{NMR}\left(500 \mathrm{MHz}, \mathrm{C}_{6} \mathrm{D}_{6}\right) \delta: 1.24$ (s, $\left.3 \mathrm{H}\right), 1.36$ (s, $3 \mathrm{H}$ ), 1.57 (quintet, $J=8 \mathrm{~Hz}, 2 \mathrm{H}$ ), 1.86 (quartet, $J=7 \mathrm{~Hz}, 2 \mathrm{H}$ ), 2.07 (t, $J=7 \mathrm{~Hz}, 2 \mathrm{H}$ ), 3.45 (dd, $J=8 \mathrm{~Hz}, 6 \mathrm{~Hz}, 1 \mathrm{H}$ ), 3.66 (dd, $J=8 \mathrm{~Hz}, 6$ $\mathrm{Hz}, 1 \mathrm{H}), 3.95-4.05(\mathrm{~m}, 3 \mathrm{H}), 4.91-4.96(\mathrm{~m}, 2 \mathrm{H}), 5.56-5.64(\mathrm{~m}, 1 \mathrm{H}) ;{ }^{13} \mathrm{C}$ NMR $\left(125 \mathrm{MHz}, \mathrm{C}_{6} \mathrm{D}_{6}\right) \delta: 24.6,25.9,27.3,33.6,33.7$, 65.0, 66.7, 74.3, 110.0, 115.8, 138.3, 173.0; Exact mass calcd for $\left(\mathrm{C}_{12} \mathrm{H}_{20} \mathrm{O}_{4}\right)_{2} \mathrm{Na}^{+}$: 479.2615; found (electrospray) $\mathrm{m} / \mathrm{z}: 479.2615$; Anal calcd for $\mathrm{C}_{12} \mathrm{H}_{20} \mathrm{O}_{4}$ : C, 63.14; $\mathrm{H}, 8.83$; found: $\mathrm{C}, 62.94 ; \mathrm{H}, 8.70$.

51 -Octyne (97\%) and iodine crystals (ACS reagent grade, $299.8 \%$ ) were purchased from Aldrich and used as received. The $n$ butyllithium solution was purchased from Aldrich, transferred to a Schlenck flask upon receipt, and titrated immediately prior to use by the method of Kofron (Kofron, W.G. and Baclawski, L.M. J. Org. Chem. 1976. 41 (10), 1879). Anhydrous diethyl ether (Certified ACS, BHT stabilized) was purchased from Fisher and purified using the solvent purification system described in Note 1 . Hexanes were purchased from Fisher (Certified ACS) and dried over microwave-activated 4 Å beaded molecular sieves $(5 \mathrm{~g} / 100 \mathrm{~mL})$ for at least $12 \mathrm{~h}$. The submitters purchased anhydrous diethyl ether (Certified ACS) and hexanes (ACS reagent grade) from Fisher and distilled them from sodium.

${ }^{6}$ The submitters used $70 \mathrm{~mL}$ hexanes.

${ }^{7}$ The checkers achieved the desired internal temperature by adjusting the depth of the flask in the dry ice/acetone bath. The submitters used a chloroform/dichloromethane-dry ice bath.
} 
precipitate begins to form less than $1 \mathrm{~min}$ into the addition. Upon completion of the addition, the flask is fully submersed in the dry ice bath to bring the internal temperature to $-70{ }^{\circ} \mathrm{C}$.

The viscous reaction mixture is stirred vigorously at this temperature for $1.5 \mathrm{~h}$. On occasion, the stir bar stops stirring in the thick slurry and is dislodged using the thermometer. During this time, a flame-dried, 500-mL pear-shaped flask is charged with iodine $(25.4 \mathrm{~g}, 100$ mmol, 1.0 equiv) (Note 5). The flask is sealed with a rubber septum, evacuated $(<1 \mathrm{mmHg})$ and refilled with nitrogen, and diethyl ether $(100 \mathrm{~mL}$ ) (Note 5) is added via a $20-\mathrm{mL}$ plastic syringe. The resulting suspension is swirled vigorously by hand for approximately $5 \mathrm{~min}$ before the deep red supernatant is transferred to the pressure-equalizing addition funnel via cannula. The residual solid iodine is taken up with vigorous stirring in $30 \mathrm{~mL}$ of diethyl ether, which is again transferred to the addition funnel via cannula. Finally, the sides of the addition funnel are rinsed with approximately $10 \mathrm{~mL}$ of ether using a 20 -mL plastic syringe, and the ethereal solution of iodine is added dropwise over $25 \mathrm{~min}$ (Note 8) to the stirring slurry of acetylide. Upon completion of the addition, a substantial mass of iodine is scraped from the tip of the addition funnel into the reaction vessel using a spatula. The cold bath is removed, and the solution is allowed to warm to $20^{\circ} \mathrm{C}$ over $2.5 \mathrm{~h}$. A septum is removed, and distilled water $(100 \mathrm{~mL})$ is added cautiously through the open neck. The resulting biphasic mixture is transferred to a 1-L separatory funnel, and the organic phase is isolated. The aqueous phase is extracted with hexanes $(100 \mathrm{~mL})$, and the combined organic phases are washed with two $200-\mathrm{mL}$ portions of water, followed by $50 \mathrm{~mL}$ of saturated aqueous sodium thiosulfate. The organic phase is dried over anhydrous magnesium sulfate $(20 \mathrm{~g})$, filtered through a Büchner funnel $(150 \mathrm{mmHg})$, and concentrated by rotary evaporation $\left(<30^{\circ} \mathrm{C}, 20\right.$ $\mathrm{mmHg}$ ) to give a clear, light yellow oil that is transferred to a $50-\mathrm{mL}$ round-bottom flask and distilled under vacuum using a short-path still (Note 9) to give $19.9 \mathrm{~g}(84 \%)$ of iodoalkyne 4 as a clear, colorless liquid (Note 10).

\section{C. (Z)-1-lodo-1-octene (5)}

A flame-dried, 250-mL, three-necked round-bottomed flask under an atmosphere of nitrogen, containing an oval-shaped magnetic stir bar $(4 \mathrm{~cm} \times 1.5 \mathrm{~cm})$, and fitted with three rubber septa is charged via plastic syringes with borane dimethyl sulfide complex $(7.51 \mathrm{~mL}$, $6.02 \mathrm{~g}, 79.2 \mathrm{mmol}, 1.06$ equiv) and diethyl ether $(75 \mathrm{~mL})$ (Note 11). The resulting stirred solution is submersed in an ice-bath for $10 \mathrm{~min}$ before cyclohexene $(16.0 \mathrm{~mL}, 13.0 \mathrm{~g}, 158$ mmol, 2.11 equiv) (Note 11) is added dropwise over $10 \mathrm{~min}$ via a 20 -mL plastic syringe. A white precipitate appears within the final minute of the addition. After $15 \mathrm{~min}$, the ice bath is

\footnotetext{
${ }^{8}$ The submitters reported an addition time of $45 \mathrm{~min}$.

${ }^{9}$ The distillation must be carried out below $100{ }^{\circ} \mathrm{C}$. On one occasion when the bath temperature exceeded $150{ }^{\circ} \mathrm{C}$, the contents of the flask changed from light yellow to dark red in color, bumped vigorously, and poured over into the receiving flask. Submitters performed the distillation at $0.85 \mathrm{mmHg}$ and recorded a bp of $63-65^{\circ} \mathrm{C}$.

${ }^{10}$ The submitters reported a yield of $77 \%$, and that the product turns pink on standing at room temperature due to residual iodine (color can be removed by an additional aqueous sodium thiosulfate wash). The checkers found the product to remain colorless over a period of several months when stored in a refrigerator under a nitrogen atmosphere. Iodoalkyne $\mathbf{4}$ exhibits the following properties: bp: $70-72{ }^{\circ} \mathrm{C}(2 \mathrm{mmHg}) ; \mathrm{IR}$ (neat) $\mathrm{cm}^{-1}: 2187 ;{ }_{1}^{1} \mathrm{H} \mathrm{NMR}\left(500 \mathrm{MHz}, \mathrm{CDCl}_{3}\right) \delta: 0.89(\mathrm{t}, J=7 \mathrm{~Hz}, 3 \mathrm{H}), 1.30-1.40(\mathrm{~m}, 6 \mathrm{H}), 1.50$ (quintet, $J=7 \mathrm{~Hz}, 2 \mathrm{H}), 2.35(\mathrm{t}, J=7 \mathrm{~Hz}, 2 \mathrm{H}) ;{ }^{13} \mathrm{C} \mathrm{NMR}\left(125 \mathrm{MHz}, \mathrm{CDCl}_{3}\right) \delta:-7.4,14.3,21.0,22.7,28.7,31.5$, 95.0; Anal calcd for $\mathrm{C}_{8} \mathrm{H}_{13} \mathrm{I}: \mathrm{C}, 40.70$; $\mathrm{H}, 5.55$; found: $\mathrm{C}, 40.54 ; \mathrm{H}, 5.44$.

${ }^{11} \mathrm{BH}_{3} \cdot \mathrm{Me}_{2} \mathrm{~S}$ complex (purity not indicated) was purchased from Aldrich and used as received. Cyclohexene (inhibitor-free, $99 \%$ ) was purchased from Aldrich and distilled prior to use. Acetic acid (ACS reagent grade) was purchased from Fisher and used as received. Anhydrous diethyl ether (Certified ACS, BHT stabilized) was purchased from Fisher and purified as described in Note 1. The submitters purchased anhydrous diethyl ether (Certified ACS, BHT stabilized) from Fisher and distilled it from sodium prior to use.
} 
removed and stirring is continued for $1 \mathrm{~h}$. The reaction flask is again placed in an ice bath and, after $5 \mathrm{~min}$, treated with iodoalkyne 4 ( $75 \mathrm{mmol}, 17.7 \mathrm{~g}$ ), added dropwise over $10 \mathrm{~min}$ via a $10-\mathrm{mL}$ plastic syringe. The solution is stirred for $30 \mathrm{~min}$, the ice bath is removed, and stirring is continued for $1.25 \mathrm{~h}$. The flask is once more immersed in the ice bath, and the mixture is allowed to stir for $15 \mathrm{~min}$ before a septum is removed and glacial acetic acid (30 $\mathrm{mL}$ ) (Note 11) is added slowly via a $100 \mathrm{~mL}$ graduated cylinder. After replacing the septum, the ice bath is removed and the mixture is stirred for $2.25 \mathrm{~h}$. Finally, the mixture is diluted with diethyl ether $(30 \mathrm{~mL})$ (Note 11$)$ and deionized water $(50 \mathrm{~mL})$. The resulting biphasic mixture is transferred to a $500-\mathrm{mL}$ separatory funnel, shaken, and the aqueous phase is discarded. The organic phase is washed with water $(3 \times 50 \mathrm{~mL})$, and dried over magnesium sulfate $(5 \mathrm{~g})$. The drying agent is removed by vacuum filtration $(150 \mathrm{mmHg})$, and the filtrate is concentrated by rotary evaporation $\left(<30^{\circ} \mathrm{C}, 20 \mathrm{mmHg}\right)$ to give a clear oil, containing small amounts of a white precipitate. This suspension is applied to a silica plug and eluted with hexanes (Note 12). Fractions containing the product are concentrated by rotary evaporation $\left(<30^{\circ} \mathrm{C}, 20 \mathrm{mmHg}\right.$ ) and the resulting yellow oil is distilled under vacuum using a short-path still to give $14.28 \mathrm{~g}(80 \%)$ of iodoalkene $\mathbf{5}$ as a clear, pale-yellow liquid (Note 13).

\section{D. (2,2-Dimethyl-1,3-dioxolan-4-yl)methyl (Z)-tetradec-7-enoate (6)}

A flame-dried, 500-mL, three-necked round-bottomed flask equipped with a cylindricalshaped magnetic stirbar $(4 \mathrm{~cm} \times 1 \mathrm{~cm})$ and 2 rubber septa is charged through the open neck with ester 2 (5.0 g, $21.9 \mathrm{mmol})$. A third septum is added, the flask is evacuated $(<1 \mathrm{mmHg})$ and refilled with nitrogen by piercing a septum with a needle connected to a Schlenck manifold. Tetrahydrofuran $(70 \mathrm{~mL}$ ) (Note 14$)$ is added via a $20-\mathrm{mL}$ plastic syringe. The flask is submersed in an ice bath, and the solution is stirred for $5 \mathrm{~min}$ before it is treated with a $0.5 \mathrm{M}$ solution of 9-borabicyclo[3.3.1]nonane [9-BBN] in THF (46 mL, $23.0 \mathrm{mmol}, 1.05$ equiv) (Note 14), added dropwise over $12 \mathrm{~min}$ via a 20-mL plastic syringe. Upon completion of the addition, the cold bath is removed and the reaction mixture is stirred for $2.5 \mathrm{~h}$, then quenched with deionized water $(70 \mathrm{~mL})$, added slowly through an open neck via a $100 \mathrm{~mL}$ graduated cylinder. The septum is replaced, and the flask is evacuated $(<1$ $\mathrm{mmHg}$ ) and refilled with nitrogen. The resulting suspension is stirred for $2.5 \mathrm{~h}$, after which time it is sparged with argon for 15 min (Note 15).

\footnotetext{
12 The checkers prepared the silica plug by wet-packing a $7.5-\mathrm{cm}$ diameter column with a slurry of $100 \mathrm{~g}$ silica gel (purchased from Zeochem, ZEOprep 60, 40-63 micron particle size) in hexanes. The crude product is loaded neat, and eluted with hexanes. Fractions $(50 \mathrm{~mL}$ ) are collected and analyzed by TLC (Whatman $0.25 \mathrm{~mm} 60 \AA$ A silica gel plates; hexanes eluent; potassium permanganate stain). This procedure removed most, but not all, of the dicyclohexylborinic acid. The submitters used a 2-cm diameter column containing $30 \mathrm{~g}$ of silica gel, and eluted with pentanes. For an alternate method of removing the dicyclohexylborinic acid via precipitation, see Brown, H.C. et al. J. Org. Chem. 1989. 54, 6064-6067.

${ }^{13}$ The submitters obtained a yield of $86 \%$. Iodoalkene 5 exhibits the following properties: bp: $77-78{ }^{\circ} \mathrm{C}(3 \mathrm{mmHg}) ; \mathrm{IR}(\mathrm{neat}) \mathrm{cm}^{-1}$. 1609; ${ }^{1} \mathrm{H}$ NMR $\left(500 \mathrm{MHz}, \mathrm{C}_{6} \mathrm{D}_{6}\right) \delta: 0.86(\mathrm{t}, J=7 \mathrm{~Hz}, 3 \mathrm{H}), 1.14-1.23(\mathrm{~m}, 8 \mathrm{H}), 2.02$ (quartet, $\left.J=7 \mathrm{~Hz}, 2 \mathrm{H}\right), 5.75$ (quartet, $J=7$ $\mathrm{Hz}, 1 \mathrm{H}), 5.90(\mathrm{dt}, J=7 \mathrm{~Hz}, 1 \mathrm{~Hz}, 1 \mathrm{H}) ;{ }^{13} \mathrm{C}$ NMR $\left(125 \mathrm{MHz}, \mathrm{C}_{6} \mathrm{D}_{6}\right) \delta: 14.6,23.3,28.6,29.4,32.3,35.3,82.7,141.8$; Anal calcd for ${ }_{1} \mathrm{H}_{15} \mathrm{I}: \mathrm{C}, 40.35$; $\mathrm{H}, 6.35$; found: $\mathrm{C}, 40.47,6.38$.

${ }^{14}$ The 9-borabicyclo[3.3.1]nonane [9-BBN] solution, cesium carbonate (99\%) and triphenylarsine (97\%) were purchased from Aldrich and used as received. Dichloro[1,1'-bis(diphenylphosphino)ferrocene]-palladium(II)-dichloromethane adduct $\left(\mathrm{Pd}(\mathrm{dppf}) \mathrm{Cl}_{2} \cdot \mathrm{CH}_{2} \mathrm{Cl}_{2}\right.$ ) was purchased from Strem and used as received. THF (Optima, Inhibitor-free) was purchased from Fisher and purified using the solvent purification system described in Note 1. DMF (99.8\%, extra dry over molecular sieves) was purchased from Acros Organics and purified using the solvent purification system described in Note 1.

${ }^{15}$ Sparging is accomplished as follows: one of the septa is pierced with a 1.5 inch, 16.5 gauge needle, and a second with a 8 inch, 20 gauge needle connected to an argon cylinder. Gentle stirring is maintained as argon is bubbled through the suspension.
} 
A separate flame-dried, 1-L, 3-necked round-bottomed flask equipped with a oval-shaped magnetic stir bar $(4 \mathrm{~cm} \times 1.5 \mathrm{~cm})$ and two rubber septa is charged through the open neck with vinyl iodide 5 ( $6.25 \mathrm{~g}, 26.3 \mathrm{mmol}, 1.2$ equiv), cesium carbonate ( $7.14 \mathrm{~g}, 21.9 \mathrm{mmol}, 1.0$ equiv) and triphenylarsine ( $0.67 \mathrm{~g}, 2.2 \mathrm{mmol}, 0.10$ equiv) (Note 14). A third septum is added, the flask is evacuated (>1 mmHg) and refilled with nitrogen, and DMF $(130 \mathrm{~mL})$ (Note 14) is added via a 20-mL plastic syringe. The resulting suspension is sparged with argon for 15 min (Note 15). Dichloro[1, $1^{\prime}-$ bis(diphenylphosphino)ferrocene]palladium(II)•dichloromethane adduct ( $\left.\mathrm{Pd}(\mathrm{dppf}) \mathrm{Cl}_{2} \bullet \mathrm{CH}_{2} \mathrm{Cl}_{2}\right)(0.80 \mathrm{~g}, 1.1 \mathrm{mmol}, 0.05$ equiv) (Note 14) is added quickly to the flask through an open neck, the septum is quickly replaced, and the resulting red suspension is sparged with argon for $15 \mathrm{~min}$ (during this time, the color of the solution changes from redorange to brown). The resulting degassed suspension is then treated with the aforementioned hydroboration mixture via cannula over $10 \mathrm{~min}$ (Note 16). Upon completion of the cannula transfer, the reaction vessel is evacuated $(<1 \mathrm{mmHg})$ and refilled with nitrogen, and the dark brown reaction mixture is stirred for $5 \mathrm{~h}$ before it is poured onto $500 \mathrm{~mL}$ saturated $\mathrm{NaCl}$ in a $2 \mathrm{~L}$ separatory funnel. The organic phase is isolated, and the aqueous phase is extracted with ether $(3 \times 300 \mathrm{~mL})$. The combined organic phases are dried over magnesium sulfate $(40 \mathrm{~g})$, and the drying agent is removed via vacuum filtration through a Büchner funnel $(150 \mathrm{mmHg})$. The filtrate is concentrated by rotary evaporation $\left(<30^{\circ} \mathrm{C}, 20 \mathrm{mmHg}\right)$ to give the product as a dark oil containing some residual DMF. Purification by flash chromatography on silica gel (Note 17) gives $7.12 \mathrm{~g}$ (88\%) (Note 18) of acetonide 6 as a brown oil containing 7\% (w/w) cyclooctanone (Note 19).

\footnotetext{
${ }^{16}$ The transfer is accomplished by partially evacuating the receiving flask, with the hydroboration flask under a slightly positive pressure of nitrogen.

${ }^{17} \mathrm{~A}$ flash column is prepared by wet-packing a 7.5 -cm diameter column with a slurry of $400 \mathrm{~g}$ of silica gel (purchased from Zeochem, ZEOprep 60, 40-63 micron particle size) in 5\% ethyl acetate/hexanes. The column is eluted with 5\% ethyl acetate in hexanes; $50 \mathrm{~mL}$ fractions are collected and analyzed by TLC (Whatman $0.25 \mathrm{~mm} 60$ A silica gel plates; 19:1 hexanes:ethyl acetate eluent; potassium permanganate stain). The desired compound begins to elute after $\sim 900 \mathrm{~mL}$, and elutes over $2.5 \mathrm{~L}$. The submitters performed a second flash purification in order to obtain the product as pale yellow oil. The checkers found that a second purification yielded the product as a clear, light orange oil, in $81 \%$ yield.

${ }^{18}$ The submitters reported a yield of $64 \%$ of 6 (twice chromatographed). The checkers found that when new bottles of $\mathrm{Pd}(\mathrm{dppf}) \mathrm{Cl}_{2} \cdot \mathrm{CH}_{2} \mathrm{Cl}_{2}, \mathrm{Cs}_{2} \mathrm{CO}_{3}$, and $\mathrm{AsPh}_{3}$ were used, yields were reproducibly $\sim 90 \%$. If these reagents were used after being opened and stored for several weeks, however, yields dropped to as low as 50\%. The use of fresh 9-BBN is also required. Ester 2 was recovered as the major side product in these low-yielding cases.

${ }^{19}$ The presence of cyclooctanone ${ }^{4}$ is inferred from ${ }^{1} \mathrm{H}$ NMR multiplets at $1.55,1.87$, and $2.40 \mathrm{ppm}$, and ${ }^{13} \mathrm{C}$ NMR signals at 24.9 , 25.8, 27.4, and $42.1 \mathrm{ppm}$ (the expected carbonyl resonance was not observed). The ratio of ester 6 to cyclooctanone is determined by integration of the resonances at $1.63 \mathrm{ppm}($ ester $6,2 \mathrm{H})$ and $1.55 \mathrm{ppm}$ (cyclooctanone, $4 \mathrm{H}$ ). The percent yield of 6 takes into account the presence of cyclooctanone. An analytically pure sample of $\mathbf{6}$ was prepared by chemical reduction as follows: a 25 -mL roundbottomed flask is charged with $500 \mathrm{mg}$ of the ester/cyclooctanone mixture and $20 \mathrm{mg}$ of sodium borohydride. Ethanol (10 mL) (Fisher, denatured) is added, and the resulting suspension is allowed to stir for $3 \mathrm{~h}$. Saturated aqueous $\mathrm{NaHCO}_{3}(10 \mathrm{~mL})$ is added, the aqueous phase is extracted three times with ether, and the combined organic layers are dried over $\mathrm{MgSO}_{4}$ and concentrated. TLC analysis of the oil [silica gel, ethyl acetate-hexanes, 1:3 by volume] indicated the presence of three products with $\mathrm{R}_{\mathrm{f}}$ values of 0.06 , 0.40 and 0.60 . The lowest $R_{\mathrm{f}}$ spot had the same TLC mobility as an authentic sample of cyclooctanol. This material was purified by chromatography over $30 \mathrm{~g}$ of silica gel, eluted with ethyl acetate-hexanes $\left(1: 15\right.$ by volume) to give $(Z)$-ethyl 7-tetradecenoate $\left(R_{\mathrm{f}}=\right.$ $0.60)$ and pure ester 6, which exhibits the following spectral properties: IR (neat) $\mathrm{cm}^{-1}: 1742$; ${ }^{1} \mathrm{H}$ NMR $\left(500 \mathrm{MHz}, \mathrm{CDCl}_{3}\right) \delta: 0.87(\mathrm{t}$, $J=7 \mathrm{~Hz}, 3 \mathrm{H}$ ), $1.2-1.5(\mathrm{~m}, 18 \mathrm{H}), 1.63$ (quintet, $J=7 \mathrm{~Hz}, 2 \mathrm{H}$ ), 2.01 (quintet, $J=7 \mathrm{~Hz}, 4 \mathrm{H}$ ), $2.34(\mathrm{t}, J=7 \mathrm{~Hz}, 2 \mathrm{H}$ ), 3.73 (dd, $J=8$ $\mathrm{Hz}, 6 \mathrm{~Hz}, 1 \mathrm{H}), 4.05-4.10(\mathrm{~m}, 3 \mathrm{H}), 4.31$ (quintet, $J=6 \mathrm{~Hz}, 1 \mathrm{H}), 5.29-5.38(\mathrm{~m}, 2 \mathrm{H}),{ }^{13} \mathrm{C}$ NMR $\left(125 \mathrm{MHz}, \mathrm{CDCl}_{3}\right) \delta: 14.3,22.9$, 25.0, 25.6, 26.9, 27.2, 27.5, 29.0, 29.2, 29.6, 29.9, 32.0, 34.3, 64.8, 66.6, 74.9, 110.1, 129.6, 130.5, 173.8; Exact mass calcd for $\mathrm{C}_{20} \mathrm{H}_{36} \mathrm{O}_{4} \mathrm{Na}^{+}: 363.2506$; found (electrospray) $\mathrm{m} / \mathrm{z}: 363.2503$; Anal calcd for $\mathrm{C}_{20} \mathrm{H}_{36} \mathrm{O} 4$ : C, $70.55 ; \mathrm{H}, 10.66$; found: $\mathrm{C}, 70.21 ; \mathrm{H}$, 10.51 .
} 


\section{E. 2,3-Dihydroxypropyl (Z)-tetradec-7-enoate (7)}

A 250-mL round-bottomed flask equipped with a oval-shaped magnetic stir bar ( $4 \mathrm{~cm} \times 1.5$ $\mathrm{cm})$ is charged with acetonide $6(4.80 \mathrm{~g}, 14.1 \mathrm{mmol})$, methanol $(60 \mathrm{~mL})$, and $2.0 \mathrm{M}$ hydrochloric acid $(4.0 \mathrm{~mL}$ ). (Note 20 ) The flask is sealed with a rubber septum and the reaction mixture is allowed to stir for $6 \mathrm{~h}$. After this time, the reaction mixture is poured into a 1-L separatory funnel containing a mixture of ether $(350 \mathrm{~mL})$ and saturated sodium bicarbonate $(350 \mathrm{~mL})$. The funnel is swirled gently to release carbon dioxide. The organic phase is separated, and the aqueous phase is extracted with ether $(3 \times 150 \mathrm{~mL})$. The combined organic phases are dried over magnesium sulfate $(20 \mathrm{~g})$, which is removed by vacuum filtration through a Büchner funnel $(150 \mathrm{mmHg})$. The filtrate is concentrated by rotary evaporation at $\left(<30^{\circ} \mathrm{C}, 20 \mathrm{mmHg}\right)$ to give an orange oil that is purified by flash chromatography on silica gel (Note 21) to give $3.02 \mathrm{~g} \mathrm{(71 \% )} \mathrm{of} \mathrm{monoacylglycerol} 7$ as an orange oil. This sample is a 20:1 mixture of 1-monoacylglycerol (1-MAG) 7 and the corresponding 2-MAG, respectively (Notes $22,{ }^{23}$, and ${ }^{24}$ ). If desired, the sample can be enriched further in the desired 1-MAG by recrystallization (Note 25).

\section{Safety and Waste Disposal Information}

All hazardous materials should be handled and disposed of in accordance with "Prudent Practices in the Laboratory"; National Academies Press; Washington, DC, 2011.

\section{Discussion}

The use of unsaturated 1-monoacylglycerols (1-MAGs) of type 8 (Figure 1) for crystallizing membrane proteins by the in meso method has steadily increased. ${ }^{5-7}$ Whereas several 1MAGs of type $\mathbf{8}$ are commercially available, many 1-MAGs of interest for protein

\footnotetext{
${ }^{20}$ Methanol (HPLC grade) and hydrochloric acid (Certified ACS) were purchased from Fisher and used as received.

${ }^{21}$ A flash column is prepared by wet-packing a $7.5-\mathrm{cm}$ diameter column with a slurry of $400 \mathrm{~g}$ of silica gel (purchased from Zeochem, ZEOprep 60, 40-63 micron particle size) in 37\% ethyl acetate/hexanes. The column is eluted with $1 \mathrm{~L}$ of $37 \%$ ethyl acetate in hexanes, followed by $50 \%$ ethyl acetate in hexanes. Fractions $(50 \mathrm{~mL}$ ) are collected and analyzed by TLC (Whatman $0.25 \mathrm{~mm} 60 \AA$ silica gel plates; 1:1 hexanes:ethyl acetate eluent; potassium permanganate stain). The desired compound begins to elute after $\sim 1.95 \mathrm{~L}$, and elutes over $1.4 \mathrm{~L}$.

22 The submitters reported a yield of $78 \%$ using 6 that had been purified twice by column chromatography (see Note 17).

${ }^{23}$ Purified 7 (containing 5\% of the corresponding 2-MAG) exhibited the following spectral properties: IR (neat) $\mathrm{cm}^{-1}$ : 1740 ; ${ }^{1} \mathrm{H}$ $\operatorname{NMR}\left(500 \mathrm{MHz}, \mathrm{CDCl}_{3}\right) \delta: 0.88(\mathrm{t}, J=7 \mathrm{~Hz}, 3 \mathrm{H}), 1.26-1.35(\mathrm{~m}, 12 \mathrm{H}), 1.64$ (quintet, $\left.J=8 \mathrm{~Hz}, 2 \mathrm{H}\right), 2.02$ (quintet, $J=7 \mathrm{~Hz}, 4 \mathrm{H}$ ), $2.35(\mathrm{t}, J=8 \mathrm{~Hz}, 2 \mathrm{H}), 3.59(\mathrm{dd}, J=12 \mathrm{~Hz}, 6 \mathrm{~Hz}, 1 \mathrm{H}), 3.69(\mathrm{dd}, J=12 \mathrm{~Hz}, 4 \mathrm{~Hz}, 1 \mathrm{H}), 3.93$ (quintet, $J=6 \mathrm{~Hz}, 1 \mathrm{H}), 4.11-4.20(\mathrm{~m}, 2$ $\mathrm{H}), 5.35$ (m, $2 \mathrm{H}) ;{ }^{13} \mathrm{C} \mathrm{NMR}\left(125 \mathrm{MHz}, \mathrm{CDCl}_{3}\right) \delta: 14.3,22.8,25.0,27.1,27.4,28.9,29.1,29.5,29.9,31.9,34.3,63.5,65.3,70.4$ Signals at $3.82(\mathrm{~d}, J=5 \mathrm{~Hz}, 4 \mathrm{H})$ and 4.92 (quintet, $J=5 \mathrm{~Hz}, 1 \mathrm{H})$ in the ${ }^{1} \mathrm{H}$ spectrum and at $62.3,75.1$ in the ${ }^{13} \mathrm{C}$ spectrum are attributed to the 2-MAG; Exact mass calcd for $\mathrm{C}_{17} \mathrm{H}_{32} \mathrm{O}_{4} \mathrm{Na}^{+}$: 323.2193; found (electrospray) $\mathrm{m} / \mathrm{z}$ : 323.2189; Anal calcd for $\mathrm{C}_{17} \mathrm{H}_{32} \mathrm{O}_{4}$ : C, 67.96; H, 10.74; found: $\mathrm{C}, 67.97 ; \mathrm{H}, 10.59$.

${ }^{24}$ The submitters utilized DMSO-d 6 for the acquisition of NMR spectra. ${ }^{1} \mathrm{H}$ NMR $(500 \mathrm{MHz}$, DMSO-d 6 ) $\delta: 0.86(\mathrm{t}, J=7,3 \mathrm{H})$, $1.26-1.30(\mathrm{~m}, 12 \mathrm{H}), 1.53$ (quintet, $J=7,2 \mathrm{H}), 1.98-2.01(\mathrm{~m}, 4 \mathrm{H}), 2.38(\mathrm{t}, J=7,2 \mathrm{H}), 3.31-3.38(\mathrm{~m}, 2 \mathrm{H}), 3.63(\mathrm{~m}, 1 \mathrm{H}), 3.91(\mathrm{dd}, J$ $=11.0,6.5,1 \mathrm{H}), 4.04(\mathrm{dd}, J=11.0,4.5,1 \mathrm{H}), 4.59\left(\mathrm{t}, J=5.5,1 \mathrm{H}, \mathrm{CH}_{2} \mathrm{OH}\right), 4.82(\mathrm{~d}, J=5.5,1 \mathrm{H}, \mathrm{CHOH}), 5.33,(\mathrm{~m}, 2 \mathrm{H}) ;{ }^{13} \mathrm{C} \mathrm{NMR}$ $(125 \mathrm{MHz}$, DMSO-d 6$) \delta: 14.4,22.2,24.8,27.0,27.1,28.6,28.8,29.3,29.6,31.6,33.9,63.1,66.0,69.8,129.9,130.1,173.3$.

$25 \mathrm{~A}$ sample of a mixture of 1-monoacylglycerol and 2-monoacylglycerol (1-MAG and 2-MAG) (3.3 g, $11.0 \mathrm{mmol})$ is added to an oven-dried $50 \mathrm{~mL}$ round-bottomed flask equipped with a sidearm, magnetic stir bar, and two rubber septa. The flask is evacuated and refilled with nitrogen, and a 1:9 solution of diethyl ether:petroleum ether $(27 \mathrm{~mL})$ is added via a $10-\mathrm{mL}$ plastic syringe. The flask is submersed in a dry ice/acetonitrile bath, and the solution is allowed to stir for $10 \mathrm{~min}$, during which time a white solid forms. The solid is allowed to settle for 5 min before the flask is tilted to one side (approximately $30^{\circ} \mathrm{C}$ ), and as much supernatant as possible is removed via syringe. The residual white suspension is washed 3 times with a 9:1 solution of ether:petroleum ether pre-cooled in an ice/water bath $(8 \mathrm{~mL}$ ) (each time, the suspension is stirred for $\sim 1 \mathrm{~min}$, and allowed to settle for $5 \mathrm{~min}$ before withdrawing as much supernatant as possible through the side arm via syringe). Finally, the cold bath is removed (the precipitate dissolves quickly upon removal of the bath), and the resulting solution is concentrated to give $1.55 \mathrm{~g} \mathrm{(47 \% )}$ of 7 as a clear, light yellow oil.
} 
crystallization studies cannot be purchased. ${ }^{8}$ Thus, there is a need for reliable methods for the preparation of 1-MAGs of type $\mathbf{8} .^{9}$

Several procedures for preparing fatty acids that appear in $\mathbf{8}$ have been described. For example, hydrogenation of alkynoic acids, ${ }^{10}$ or Wittig reactions between aldehydes and phosphoranes, ${ }^{11}$ have been used to prepare fatty acids that might be useful for the preparation of commercially unavailable 1-MAGs.

An issue in any general synthetic approach to 1-MAGs of type $\mathbf{8}$ is preparation of the Zolefin with good control of stereochemistry. The Suzuki-Miyaura reaction is a reliable method for the preparation of either $E$ - or $Z$-olefins. ${ }^{12}$ This reaction involves hydroboration of an alkene followed by Pd-mediated coupling of the intermediate borane with a 1halogenated alkene with retention of haloalkene stereochemistry. This procedure describes use of the Suzuki-Miyaura reaction in a modular approach to 1-MAGs of type 8 (Figure 2) within the context of a synthesis of 7.7-MAG (7).

The coupling partners used in this synthesis of 1-MAGs are 1-iodoalkenes (10) and esters (9) derived from terminal alkenoic acids and solketal. Iodoalkenes can be prepared by a variety of methods. ${ }^{13}$ This procedure uses the method of Brown involving conversion of a terminal alkyne to the corresponding 1-iodoalkyne, followed by a hydroborationprotonolysis to afford the terminal Z-1-iodoalkene. ${ }^{14}$ We note that the preparation of Z-1iodooctene presented here is modeled directly after the Denmark synthesis of Z-1iodoheptene that appears in Volume 81 of Organic Syntheses. ${ }^{15}$ The esters (9) can be prepared by DCC-mediated coupling of the corresponding unsaturated acid with solketal. ${ }^{3}$ The Suzuki-Miyaura coupling is accomplished using $\operatorname{Pd}(\mathrm{dppf}) \mathrm{Cl}_{2} \cdot \mathrm{CH}_{2} \mathrm{Cl}_{2}$ as the catalyst with triphenylarsine as an additive (the "Johnson-Braun" modification). ${ }^{17}$ This affords the 1MAG acetonide (11), which is then hydrolyzed to the corresponding 1-MAG. Whereas the 1-MAG acetonides can be obtained in pure form from this procedure, the hydrolysis results in some isomerization of the 1-MAG to the corresponding 2-MAG (5-10\%) in which the acyl group resides at the 2-position of glycerol. ${ }^{16}$ The final 1-MAG, however, can usually be recrystallized to provide material contaminated with no more than $5 \%$ of the 2-MAG. Table 1 shows a variety of 1-MAG acetonides (11) and 1-MAGs (8) that have been prepared using this procedure. ${ }^{18}$

\section{Acknowledgments}

The authors acknowledge the National Institutes of Health and Science Foundation Ireland for financial support. 


\section{Biographies}

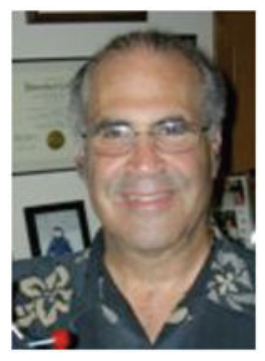

David J. Hart was born in Lansing, Michigan, USA in 1948. He received his BS degree from the University of Michigan in 1972 after serving as a conscientious objector for two years (1967-1969) during the Vietnam War. He received his PhD in 1976 with William G.

Dauben, and pursued postdoctoral studies at Caltech with David A. Evans. He moved to The Ohio State University Department of Chemistry in 1978 where he remained on the faculty for 31 years. He is now Professor Emeritus at OSU and is continuing research at a leisurely pace in the field of organic synthesis.

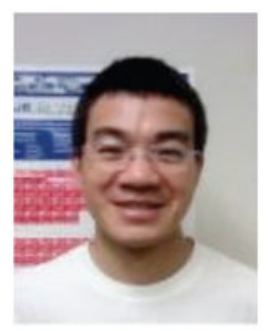

Dexi Yang was born and raised in China. He received his BS from Nanjing University in 2000 where he continued studies in bioinorganic chemistry (MS in 2003 with Wenxia Tang). He pursued graduate studies at The Ohio State University (PhD in 2008 with David J. Hart). His PhD studies focused on application of a radical cyclization strategy toward total synthesis of polyandranes and chaparrinone. He continued postdoctoral studies at Scripps Florida with Glenn C. Micalizio. Currently, he is working on application of titanium coupling reaction to stereoselective synthesis of highly substituted piperidines, indolizidines, quinolizidines and alkaloids.

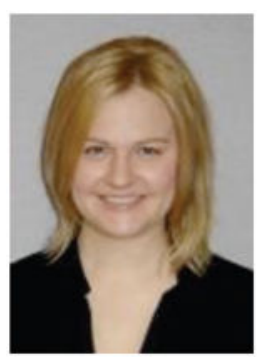

Valerie Cwynar grew up in New Castle, PA. After receiving her B.S. in 2001 from the University of Pittsburgh, she continued her studies at The Ohio State University under the direction of Professor David J. Hart. Initially, her graduate work focused on the preparation 
of synthetic lipids, and transitioned to efforts toward the synthesis of $(5 R)$ - and (5S)polyandrane. After receiving her Ph.D. in 2007, she moved to the University of Michigan to begin her postdoctoral studies under the direction of Professor Edwin Vedejs focusing on development of synthetic methodology inspired by $(R)$-telomestatin. Currently, she is a Scientist I at Vertex Pharmaceuticals Inc.

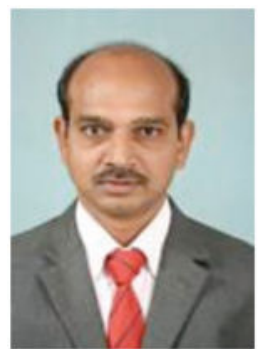

Dr. Madanmohan Jakkam was born in Andhrapradesh, India. He received his MS degree from the University of Pune, India in 1990, and his PhD at the National Chemical Laboratory in Pune. His doctoral studies were directed toward the synthesis of taxanoids and use of heterogeneous catalysts for organic transformations. He performed postdoctoral studies at National Taiwan University (synthesis of calexarines), at New Mexico State University (synthesis of perfluoro(bis)phosphonic acids), and at The Ohio State University (synthesis of monoacylglycerols). He then worked on polyamines at Medigen Biosciences in Madison, Wisconsin, and is currently a Research Scientist at GL Synthesis in Worcester, MA.

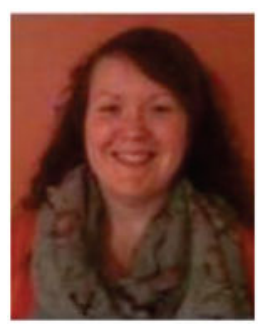

Jean P. Lee was born in Newport, Co. Tipperary, Ireland in 1978. She received her B.Sc. degree in Applied Chemistry from Kingston University, Surrey in 2000. She pursued graduate studies at the Royal College of Surgeons, Dublin (Ph.D. in 2005 with Marc Devocelle and John G. Kelly) and postdoctoral studies at the University of Limerick with Martin Caffrey from 2006-2008. She then moved from academia to industry in 2008 to a Process Specialist position for Abbott Ireland Diagnostic Division, Sligo where she is as a member of the Technical Operations Team working on process improvement projects. 


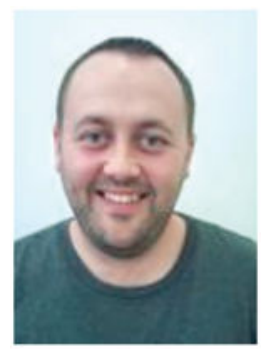

Joseph A. Lyons was born in Ennis, Co. Clare, Ireland in 1982. He received his B. Sc. degree in Industrial Chemistry from the University of Limerick in 2004. He began his graduate studies towards a $\mathrm{PhD}$ between The Ohio State University and University of Limerick with Prof. Martin Caffrey. He is currently completing his graduate thesis on the use of synthetic monoacylglycerols as hosting matrices for the crystallization of integral membrane proteins.

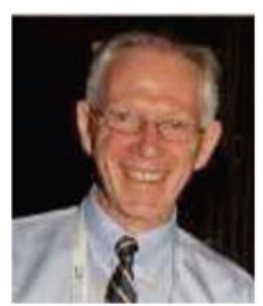

Martin Caffrey grew up in Dublin, Ireland and was awarded a first-class honours degree in Agricultural Science at University College Dublin in 1972. With an MS in Food Science and a PhD in Biochemistry from Cornell University, Ithaca, NY, he embarked on a professorial career in the Chemistry Department at the Ohio State University, Columbus, Ohio. In 2003 he returned to Ireland to establish a multi-disciplinary program in Membrane Structural and Functional Biology at the University of Limerick with funding from Science Foundation Ireland and the USA National Institutes of Health. Its mission is to establish the molecular bases for biomembrane assembly and stability and to understand how membranes transform and transmit in health and disease. In 2009, his research group moved to Dublin when Prof. Caffrey received a Personal Chair at Trinity College Dublin with joint appointments in the School of Medicine and the School of Biochemistry and Immunology.

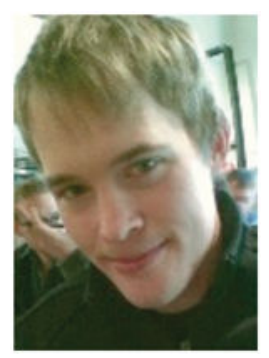

Zachary Gates received his B.S. degree in chemistry from The University of Chicago (2007), where he conducted undergraduate research in the laboratory of Stephen Kent. During this time he worked closely with graduate students Duhee Bang and Brad Pentelute 
(now Assistant professors at Yonsei University and Massachusetts Institute of Technology, respectively). Currently, Zak is a NSF predoctoral fellow in the laboratory of Viresh Rawal. Zak is broadly interested in the chemical sciences, chemical education, and the intersection of science, technology, and society. Hobbies include music, martial arts, small business, and community outreach.

\section{References}

3. Coleman BE, Cwynar V, Hart DJ, Havas F, Madanmohan J, Patterson S, Ridenour S, Schmidt M, Smith E, Wells AJ. Synlett. 2004:1339-1342.

4. Fürstner A, Seidel G. Synlett. 1998:161-162. This paper describes cyclooctanone as a minor product $(7 \%)$ in Suzuki reactions of the title reagent.

5. (a) Landau EM, Rosenbusch JP. Proc Natl Acad Sci USA. 1996; 93:14532-14535. [PubMed: 8962086] (b) Caffrey M. Curr Opin Stru Biol. 2000; 10:486-497.(c) Caffrey MJ. Struct Biol. 2003; 142:108-132.(d) Caffrey M. Ann Rev Biophys. 2009; 38:29-51. [PubMed: 19086821] (e) Cherezov V, Clogston J, Papiz MZ, Caffrey M. J Mol Biol. 2006; 357:1605-1618. [PubMed: 16490208] (f) Caffrey, M.; Lyons, J.; Smyth, T.; Hart, D.; Jin. Current Topics in Membranes. DeLucas, L., editor. Vol. 63. Burlington: Academic Press; 2009. p. 83-108.

6. Cherezov V, Caffrey M. J Appl Cryst. 2005; 38:398-400.

7. (a) Misquitta Y, Cherezov V, Havas F, Patterson S, Madanmohan J, Wells AJ, Hart DJ, Caffrey M. J Struct Biol. 2004; 148:169-175. [PubMed: 15477097] (b) Misquitta LV, Misquitta Y, Cherezov V, Slattery O, Madanmohan J, Hart D, Zhalnina M, Cramer WA, Caffrey M. Structure. 2004; 12:2113-2124. [PubMed: 15576026] (c) Rosenbaum DM, Zhang C, Lyons JA, Holl R, Aragao D, Arlow DH, Rasmussen SGF, Choi HJ, DeVree BT, Sunahara RK, Chae PS, Gellman SH, Dror RO, Shaw DE, Weis WI, Caffrey M, Gmeiner P, Kobilka BK. Nature. 2011; 469:236-240. [PubMed: 21228876] (d) Li D, Lee J, Caffrey M. Cryst Growth Des. 2011; 11:530-537.(e) Hofer N, Aragao D, Lyons JA, Caffrey M. Cryst Growth Des. 2011; 11:1182-1192.(f) Rasmussen SGF, DeVree BT, Zou Y, Kruse AC, Chung KY, Kobilka TS, Thian FS, Chae PS, Pardon E, Calinski D, Mathiesen JM, Shah STA, Lyons JA, Caffrey M, Gellman SH, Steyaert J, Skiniotis G, Weis WI, Sunahara RK, Kobilka BK. Nature. 2011 in press.

8. Monoacylglycerols such as monoolein [9.9], monopalmitolein [9.7] and monovaccenin [11.7] are commercially available. Note added in proof: Several additional 1-MAGs, including [7.7], became commercially available from Avanti Polar Lipids, Inc. late in the checking of this procedure.

9. Jensen RG, Pitas RE. Advances in Lipid Research. 1977; 14:213-247.

10. Valicenti AJ, Pusch FM, Holman RT. Lipids. 1985; 20:234-242. [PubMed: 3999930]

11. (a) Gehring L, Haase D, Habben K, Kerkhoff C, Meyer HH, Kaever V. J Lipid Res. 1998; 39:1118-1126. [PubMed: 9610781] (b) Zhang X, Schlosser M. Tetrahedron Lett. 1993; 34:19251928.

12. (a) Miyaura N, Ishiyama T, Ishikawa M, Suzuki A. Tetrahedron Lett. 1986; 27:6369-6372.(b) Miyaura N, Ishiyama T, Sasaki H, Ishikawa M, Satoh M, Suzuki A. J Am Chem Soc. 1989; 111:314-321.(c) Trauner D, Chemler SR, Danishefsky SJ. Angew Chem Int Ed. 2001; 40:45444568 .

13. (a) Alexakis A, Cahiez G, Normant JF. Organomet Chem. 1979; 177:293-298.(b) Miller RB, McGarvey G. Syn Comm. 1978; 8:291-299.(c) Stewart SK, Whiting A. Tetrahedron Lett. 1995; 36:3932-3932.(d) Stork G, Zhao K. Tetrahedron Lett. 1989; 30:2173-2174.(e) Bestmann HJ, Rippel HC, Dostalek R. Tetrahedron Lett. 1989; 30:5261-5262.

14. (a) Brown HC, Blue CD, Nelson DJ, Bhat NG. J Org Chem. 1989; 54:6064-6067.(b) Svatos A, Saman D. Collect Czech Chem Comm. 1997; 62:1457-1467.

15. Denmark SE, Wang Z. Org Syn. 2004; 81:42-53.

16. (a) Murgia S, Caboi F, Monduzzi M, Ljusberg-Wahren H, Nylander T. Progr Colloid Polym Sci. 2002; 20:41-46.(b) Lyubachevskaya G, Boyle-Roden E. Lipids. 2000; 35:1353-1358. [PubMed: 11201997]

17. Johnson CR, Braun MP. J Am Chem Soc. 1993; 115:11014-11015. 
18. An alternative approach to the synthesis of 1-monoacylglycerols was reported while this work was in the checking process. See Fu Y, Weng Y, Hong W-X, Zhang Q. Synlett. 2011:809-812.

\section{Appendix. Chemical Abstracts Nomenclature; (Registry Number)}

(2,2-Dimethyl-1,3-dioxolan-4-yl)methyl 5-hexenoate: 5-Hexenoic acid, (2,2-dimethyl-1,3dioxolan-4-yl)methyl ester; (749266-07-7)

5-Hexenoic acid; (1577-22-6)

4-(Dimethylamino)pyridine: 4-Pyridinamine, N,N-dimethyl-; (1122-58-3)

$N, N^{\prime}$-Dicyclohexylcarbodiimide; (538-75-0)

DL-1,2-Isopropylideneglycerol: 1,3-Dioxolane-4-methanol, 2,2-dimethyl-; (100-79-8)

1-Iodo-1-octyne; (81438-46-2)

1-Octyne; (629-05-0)

Iodine; (7553-56-2)

n-Butyllithium; (106-72-8)

(Z)-1-Iodo-1-octene; (52356-93-1)

Borane dimethyl sulfide complex: Boron, trihydro[thiobis[methane]]-, (T-4)-; (13292-78-0)

Cyclohexene; (110-83-8)

(2,2-Dimethyl-1,3-dioxolan-4-yl)methyl (Z)-tetradec-7-enoate: 7-Tetradecenoic acid, (2,2dimethyl-1,3-dioxolan-4-yl)methyl ester, (7Z)-; (749266-24-8)

9-Borabicyclo[3.3.1]nonane: 9-BBN; (280-64-8)

Cesium carbonate; (534-17-8)

Triphenylarsine; (603-32-7)

Dichloro[1, 1'-bis(diphenylphosphino)ferrocene]palladium(II)・ dichloromethane; (95464-05-4)

2,3-Dihydroxypropyl (Z)-tetradec-7-enoate: 7-Tetradecenoic acid, 2,3-dihydroxypropyl ester, (7Z)-; (749266-35-1) 


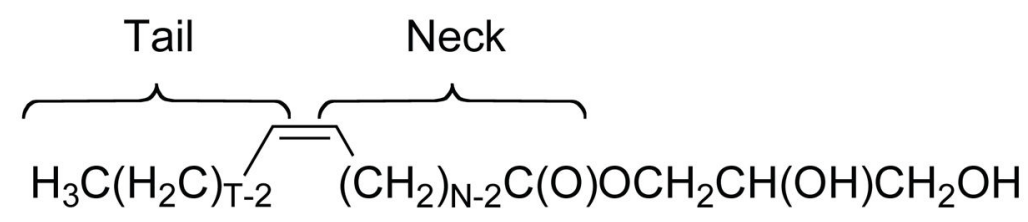

\section{N.T-MAG (8)}

Figure 1.

Neck $(\mathrm{N})$ and Tail $(\mathrm{T})$ represent the number of carbon atoms on either side of the double bond in the acyl chain. The neck and tail of 7.7-MAG (7) each have seven carbons. 


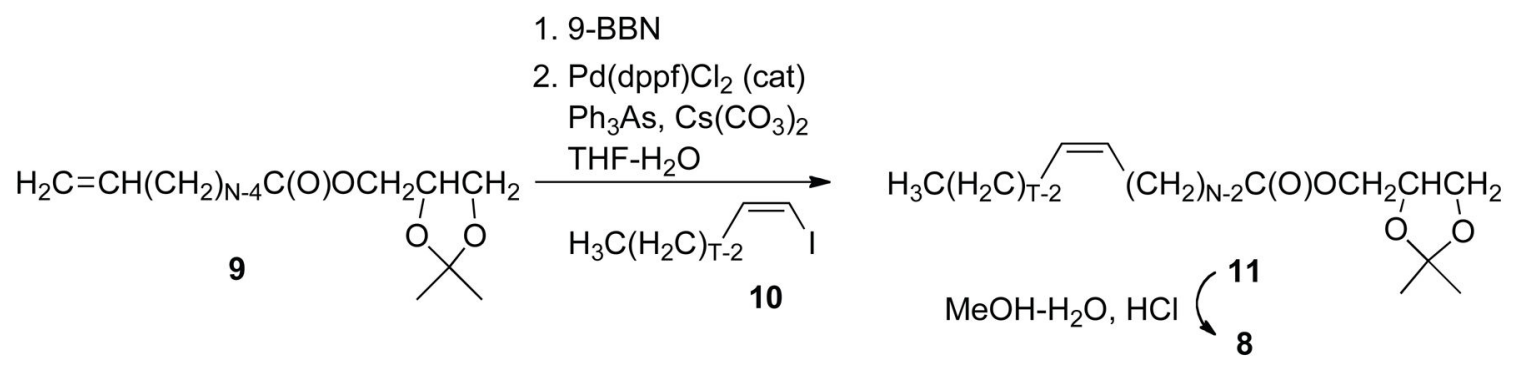

Scheme 1.

Preparation of N.T-MAGs using Suzuki-Miyaura Coupling 


\section{Table 1}

Preparation of 1-Monoacylglycerols 8 via Scheme 1

\begin{tabular}{ccl}
\hline 1-MAG [N, T] & Yield 1-MAG Acetonide (11) & Yield 1-MAG $^{\boldsymbol{a}}(\mathbf{8})$ \\
\hline$[5.7]$ & $45 \%$ & $\mathbf{8 a} 70 \%^{b}$ \\
{$[5.9]$} & $40 \%$ & $\mathbf{8 b} 56 \%^{b}$ \\
{$[5.13]$} & $78 \%$ & $\mathbf{8 c} 45 \%^{b}$ \\
{$[6.7]$} & $63 \%$ & $\mathbf{8 d} 85 \%^{b}$ \\
{$[6.12]$} & $34 \%$ & $\mathbf{8 e} 58 \%$ \\
{$[7.7]$} & $64 \%$ & $\mathbf{8 f} 78 \% b$ \\
{$[7.9]$} & $77 \%$ & $\mathbf{8 g} 45 \%$ \\
{$[7.10]$} & $70 \%$ & $\mathbf{8 h} 58 \%$ \\
{$[7.11]$} & $76 \%$ & $\mathbf{8 i} 85 \%$ \\
{$[8.7]$} & $68 \%$ & $\mathbf{8 j} 78 \%^{b}$ \\
{$[8.8]$} & $68 \%$ & $\mathbf{8 k} 46 \%$ \\
{$[8.9]$} & $64 \%$ & $\mathbf{8 1} 63 \% b$ \\
{$[8.10]$} & $53 \%$ & $\mathbf{8 m} 53 \% c$ \\
{$[9.10]$} & $68 \%$ & $\mathbf{8 0} 53 \% c$ \\
{$[10.8]$} & $61 \%$ & $\mathbf{8 p} 55 \%$ \\
{$[11.9]$} & $47 \%$ & $\mathbf{8 q} 76 \%$ \\
{$[12.6]$} & $53 \%$ & $\mathbf{8 r} 64 \%$ \\
{$[13.5]$} & $52 \%$ & $\mathbf{8 s} 48 \%$ \\
\hline
\end{tabular}

${ }^{a}$ Yield of colorless recrystallized material unless noted otherwise.

${ }^{b}$ Yield of 1-MAG from chromatography. The amount of 2-MAG in the 1-MAG follows: $\mathbf{8 a}(6 \%), \mathbf{8 b}(5 \%), \mathbf{8 c}(0 \%), \mathbf{8 d}(\operatorname{trace}), \mathbf{8 f}(7-9 \%), \mathbf{8 j}$ $(0 \%), 81(0 \%)$.

${ }^{c}$ Recrystallized 1-MAG contaminated with 2-MAG: 8m, (3\%), 8o (5\%). 